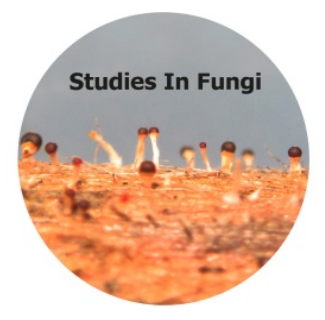

\title{
First record of Capnodium berberidis from India
}

\author{
Gautam $\mathrm{AK}^{1 *}$ and Avasthi $\mathrm{S}^{2}$ \\ ${ }^{1}$ School of Agriculture, Faculty of Science, Abhilashi University, Mandi-175028, India \\ ${ }^{2}$ Department of Botany, Abhilashi Post Graduate Institute of Sciences, Mandi-175008, India
}

Gautam AK, Avasthi S 2019 - First record of Capnodium berberidis from India. Studies in Fungi 4(1), 37-42, Doi 10.5943/sif/4/1/5

\begin{abstract}
Capnodium berberidis, a sooty mould fungus, previously reported only from Pakistan in 1978, was recently observed on Berberis lycium in Jot Pass, district Chamba of Himachal Pradesh, India. Berberis lycium is a well-known small to medium sized spiny, woody, deciduous or evergreen medicinal and ornamental plant distributed throughout temperate and subtropical regions of the world. Disease symptoms appeared as thin, black to dark brown, easily removed superficial layer of hyphae on various parts of host plant including leaves, stem, twigs and fruits. The detailed studies on its morphology and taxonomy revealed it a sooty mould fungus Capnodium berberidis. As per literature consulted, this is the first report of Capnodium berberidis from India and probably second from world.
\end{abstract}

Key words - Berberis lycium - black mildew - Dothideomycetes - Himachal Pradesh - new record - sooty moulds

\section{Introduction}

Capnodium introduced by Montagne (1849) is the type genus of Capnodiaceae (Friend 1965). Capnodiaceae is the most common family of sooty moulds belongs to order Capnodiales and class Dothideomycetes (Batista \& Ciferri 1963, Hughes 1976, Crous et al. 2009, Schoch et al. 2009, Chomnunti et al. 2011, 2014, Hyde et al. 2013, Wijayawardene et al. 2014, Liu et al. 2015). The appearance of mycelium superficially as a network of septate, dark brown hyphae on the surfaces of host with production of bitunicate asci are the main characters of this family. The production of short or long narrow necked elongated pycnidia having conspicuous oval swelling near the base, middle or apex and produce hyaline conidia inside the swollen part is found in anamorphic part (Chomnunti et al. 2011, 2014). The asexual morph and sexual morph can be found in the same or different hosts, however, for some the teleomorph is unknown (Chomnunti et al. 2011, 2014, Hyde et al. 2013). It is believed to be the largest family containing sooty mould species which causes chlorosis and plant stunting disease.

Berberis lycium is a well-known medicinal and ornamental plant distributed throughout temperate and subtropical regions of the world. It is a small to medium sized spiny, woody, deciduous or evergreen shrubs or small trees with characteristic yellow wood and yellow or orange flowers (Ahmed \& Alamgeer Sharif 2009, Sood et al. 2012). The chemical constituents include isoquinolone alkaloids, especially berberine and are used in medicine to cure the liver, neck and stomach cancer, blood purification and mouth scent (Khan et al. 2016, Chander et al. 2017). A sooty mould infection was observed on all plant parts of Berberis lycium from Jot pass area of 
district Chamba, Himachal Pradesh. Disease is easily identifiable by the presence of a black, velvety growth covering various plants parts. The fungus produces mycelium which is superficial and dark grows on the leaf, stem, flowers and sometime on fruits also. Critical morphological examination of the diseased samples revealed it to be a species of Capnodium. Therefore, the aim of this study was to investigate detailed morphological and taxonomic description of the Capnodium species and compare it with already available literature on this fungus.

\section{Materials \& Methods}

Infected plant parts of Berberis lycium were collected during winter (October 2016) in paper bags from Jot pass area of district Chamba, Himachal Pradesh, India. These infected plant parts along with a host twigs and reproductive parts were dried between sheets of blotting paper and preserved for further studies. Host plants were identified and confirmed by matching the collections with herbarium and by consulting botanists.

In the field, observations were made on few aspects, whether the disease occurs on old or young leaves or on old or young trees. Infected plant parts were observed in the field, field notes were made regarding their pathogenicity, nature of colonies, nature of infection, locality and altitude. In the field, infected plants were collected in paper bags and taken to the laboratory for identification and taxonomical studies. For herbarium, the infected plant parts were pressed neatly and dried in between blotting papers. After ensuring their dryness, they were kept in the manifold blotting or butter paper. Identified samples were deposited in the Abhilashi University Mycological Herbarium (AUMH), Abhilashi University Mandi, Himachal Pradesh, India.

The diseases symptoms were first studied with the help of magnifying lens and then examined under a stereomicroscope. Surface scraping of the aerial parts bearing the sooty mould fungus was taken and mounted in lactophenol cotton blue mixture for microscopic examination. The microscopic observations were made under oil immersion by standard light microscopy to note down characters of mycelium, pycnidia and conidia. For microscopic characters and photographs a research microscope connected with Sony DSC camera was used. All measurements were taken with the help of ToupView software. All measurements are given in the form of min-max (mean and number of measurements). The disease and pathogen was identified and compared with already available literature (Mukherji \& Juneja 1974, Bilgrami et al. 1991, Jamaluddin et al. 2004, Chomnunti et al. 2011, 2014).

\section{Results}

The sample collection site Jot Pass, is well known hill station located in district Chamba of Himachal Pradesh, India. It is located at $2300 \mathrm{~m}$ height and have heavy snow fall during winter. The species of Cedrus, Rhododendron and Quercus are chiefly found in the area along with small to medium sized woody shrubs including Berberis. The climatic conditions of the areas are quite favourable for growth of foliicolous fungi including sooty moulds (Fig. 1).

Disease symptoms appeared as thin, black to dark brown, easily removed superficial layer of hyphae. The disease symptoms usually appeared in the winter season and infect all plant parts including leaves, stem, twigs and fruits.

\section{Taxonomy}

Capnodium berberidis S. Ahmad, Monogr. Biol. Soc. Pakistan 8: 33 (1979)

Fig. 2

Fungus growing on the surface of leaves, branches, twigs and stems of Berberis lycium as thin dark brown, easily removable layer on the host surface and composed of cylindrical hyphae. Thallus of superficial mycelium $3-5 \mu \mathrm{m}$ wide $(\overline{\mathrm{x}}=4 \mu \mathrm{m}, \mathrm{n}=15)$, septate, constricted at the septum, branched, brown to dark brown. Asexual morph: Pycnidia 155-185 $\mu \mathrm{m}$ long $(\overline{\mathrm{x}}=165 \mu \mathrm{m}, \mathrm{n}=10)$, superficial, scattered or gregarious, blackish brown, cylindrical, swollen at the central part, 15-22 $\mu \mathrm{m}$ diam. $(\overline{\mathrm{x}}=30 \mu \mathrm{m}, \mathrm{n}=10)$, lacking a basal bulbous part. Wall of pycnidia comprising mostly cylindrical cells, the swollen part producing conidia inside. Ostiole of pycnidia $15-18 \mu \mathrm{m}$ diam. $(\overline{\mathrm{x}}$ 
$=15 \mu \mathrm{m}, \mathrm{n}=10)$. Conidia $4-7 \times 1-3 \mu \mathrm{m}(\overline{\mathrm{x}}=5 \times 2 \mu \mathrm{m}, \mathrm{n}=15)$, cylindrical to oblong, brown, ends round, hyaline, smooth-walled. Sexual morph: Undetermined.

Material examined - India, Himachal Pradesh, Chamba, Jot Pass, on leaves of Berberis lycium Royle (Berberidaceae), 2880 meters, 8 October 2016, A. K. Gautam, (AUMH-1034).

Known distribution - Pakistan, India.

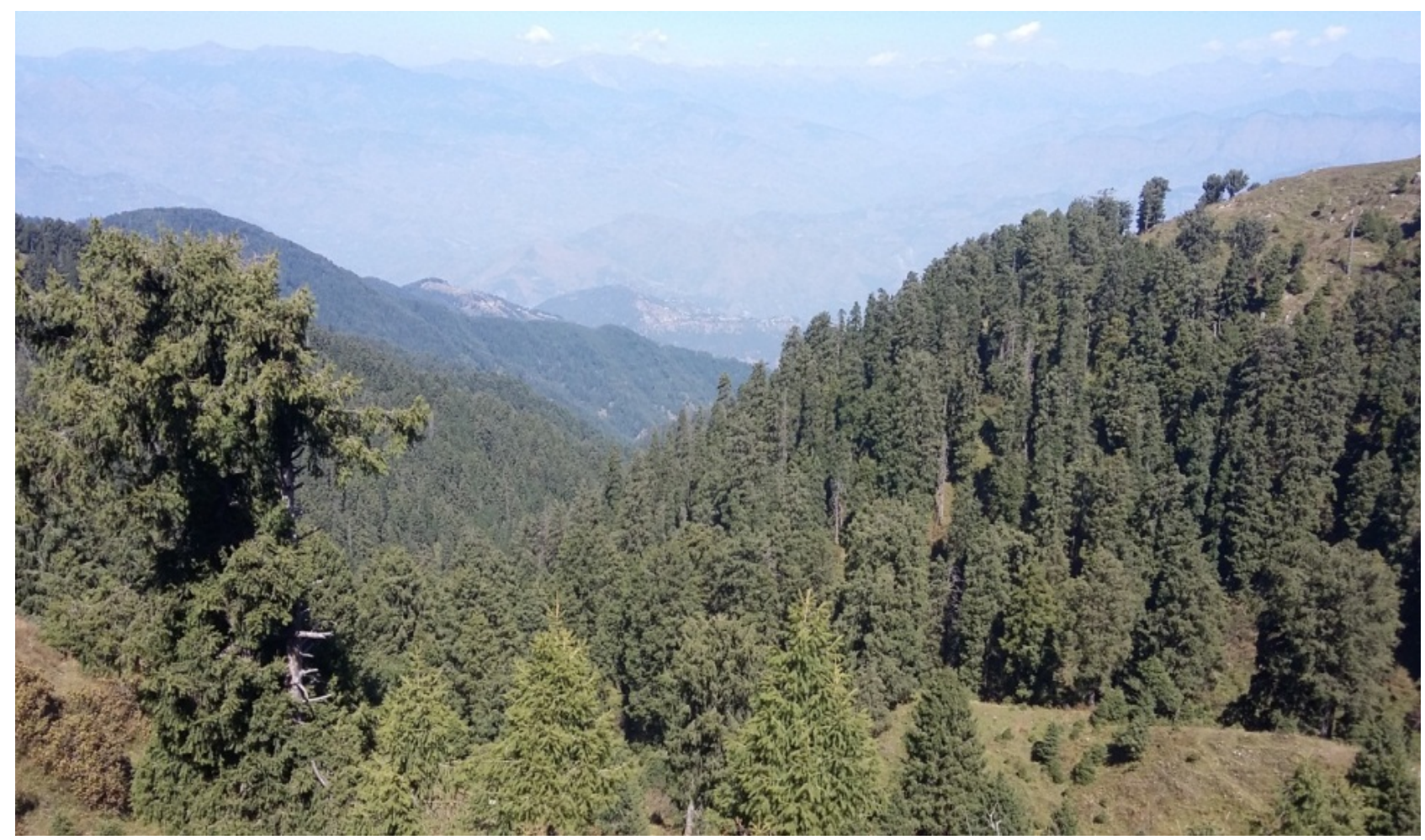

Fig. 1 - Collection site of Capnodium berberidis on Berberis lycium (Jot Pass, Chamba, Himachal Pradesh).

\section{Discussion}

Capnodium is a widely distributed genus having a wide host range. There are 140 epithets recorded on a large variety of plant hosts (www.indexfungorum.org; accessed 1 November 2018). Number of species of Capnodium has been reported across India. Previously it was observed as Capnodium citri on Citrus sp., C. eugeniarum on Ficus retusa, Agave vera-crucis (Sharma \& Mishra 2018), C. anonae on Ficus racemosa, C. ramosum on Mangifera indica, Capnodium sp. on Nyctanthes arbor-tristis (Todawat 2017). A detailed comparison of Camptomeris spp. reported worldwide along with host range is provided in this study (Table 1).

The sooty mould genus Capnodium is most commonly found in gardens and landscapes and generally recognized with their superficial black mycelia with septate, cylindrical, dark-brown hyphae, asexual morph as elongated pycnidia with short or long narrow neck. Conidia produced are released through a short opening called ostiole (Laemmlen 2011, Chomnunti et al. 2011). Based on these characters the present collection is identified as species of Capnodium. The critical analysis of morphological characters of the diseased samples and their microscopic examination revealed pathogen as fungus Capnodium berberidis.

Capnodium inhabits a wide array of hosts, no report is still available from any place of India. The occurrence of Capnodium berberidis on Berberis lycium has only been reported from Pakistan (Ahmad 1978) but not detected afterward across the globe. Therefore, we present here a new record and new addition to mycoflora of India and probably second from world. 


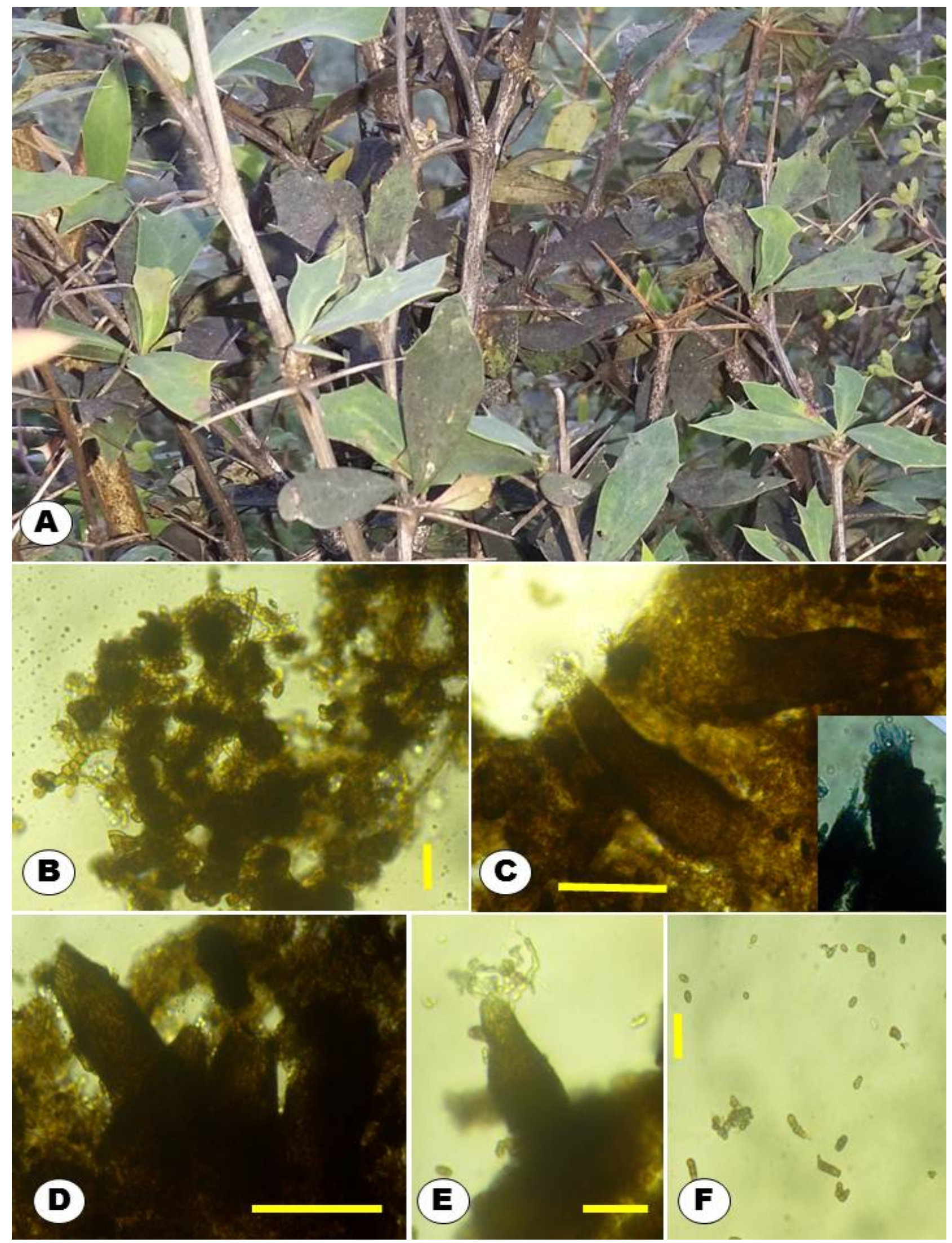

Fig. 2 - Capnodium berberidis. A Substrate. B Superficial vegetative mycelium (septate hyphae) C-E Pycnidia (Ostiole surrounded by hyaline hyphae). F conidia. Scale Bars: B=10 $\mu \mathrm{m}, \mathrm{C}-\mathrm{E}=100$ $\mu \mathrm{m}, \mathrm{f}=20 \mu \mathrm{m}$. 
Table 1 Comparison of Capnodium spp.

\begin{tabular}{|c|c|c|c|c|c|}
\hline Species & Host & $\begin{array}{l}\text { Mycelium } \\
\text { ( } \mu \text { m wide) }\end{array}$ & $\begin{array}{l}\text { Pycnidia } \\
\text { ( } \mu \mathrm{m} \text { long) }\end{array}$ & $\begin{array}{l}\text { Conidia } \\
\mu \mathrm{m}\end{array}$ & Reference \\
\hline $\begin{array}{l}\text { Capnodium berberidis S. } \\
\text { Ahmad }\end{array}$ & $\begin{array}{l}\text { Berberis } \\
\text { lycium }\end{array}$ & $3-5$ & 155-185 & $4-7 \times 1-3$ & $\begin{array}{l}\text { Ahmad 1978, } \\
\text { Present study }\end{array}$ \\
\hline $\begin{array}{l}\text { Capnodium citri Berk. \& } \\
\text { Desm }\end{array}$ & $\begin{array}{l}\text { Citrus sp., } \\
\text { Olea sp. }\end{array}$ & $4.2-6$ & 345-391 & $6.5 \times 5$ & $\begin{array}{l}\text { Rao 1970, } \\
\text { Chomnunti et al. } \\
2011\end{array}$ \\
\hline $\begin{array}{l}\text { Capnodium coartatum } \\
\text { Chomnunti \& KD Hyde }\end{array}$ & $\begin{array}{l}\text { Psidium } \\
\text { guajava }\end{array}$ & $3-5$ & $332-401$ & $\begin{array}{l}4.2- \\
4.6 \times 1.9-2.4\end{array}$ & $\begin{array}{l}\text { Chomnunti et al. } \\
2011\end{array}$ \\
\hline $\begin{array}{l}\text { Capnodium tiliae (Fuckel) } \\
\text { Sacc. }\end{array}$ & $\begin{array}{l}\text { Tilia } \\
\text { parviflora }\end{array}$ & $4-6$ & 81-136 & $13-17 \times 5-7$ & $\begin{array}{l}\text { Chomnunti et al. } \\
2011\end{array}$ \\
\hline $\begin{array}{l}\text { Capnodium coffeicola } \\
\text { Hongsanan \& K.D. Hyde }\end{array}$ & Coffea sp & $3-5$ & 165-178 & 14-16 & $\begin{array}{l}\text { Hongsanan et al. } \\
2015\end{array}$ \\
\hline
\end{tabular}

\section{Acknowledgements}

The authors gratefully thank their respective organizations for providing laboratory facilities to carry out this research work successfully. We also express our thanks for encouragement and every possible support provided by everyone during this scientific study.

\section{References}

Ahmad S. 1978 - Ascomycetes of Pakistan. Monograph II. The Biological Society of Pakistan 8, $1-144$.

Ahmed M, Alamgeer Sharif TA. 2009 - Potential adjunct to Insulin: Berberis lycium Royle. Diabetologia Croatic 38, 13-17.

Batista AC, Ciferri R. 1963 - The sooty- molds of the family Asbolisiaceae. Quaderno del Laboratorio Crittogamico del Istituto Botanico dell'Università di Pavia 31, 1-229.

Bilgrami KS, Jamaluddin, Rizwi MA. 1991 - Fungi of India: list and references. Today and Tomorrow's Printers \& Publishers, New Delhi, India.

Chander V, Aswal JS, Dobhal R, Uniyal DP. 2017 - A review on Pharmacological potential of Berberine; an active component of Himalayan Berberis. The Journal of Phytopharmacology 6, 53-58.

Chomnunti P, Hongsanan S, Aguirre-Hudson B, Tian Q et al. 2014 - The sooty moulds. Fungal Diversity 66, 1-36.

Chomnunti P, Schoch CL, Aguirre-Hudson B, KoKo TW et al. 2011 - Capnodiaceae. Fungal Diversity $51,103-134$.

Crous PW, Schoch CL, Hyde KD, Wood AR et al. 2009 - Phylogenetic lineages in the Capnodiales. Studies in Mycology 64, 17-47.

Friend RJ. 1965 - What is Fumago vagena? Transactions of the British Mycological Society. 48, 371-375.

Hongsanan S, Tian Q, Hyde KD, Chomnunti P. 2015 - Two new species of sooty moulds, Capnodium coffeicola and Conidiocarpus plumeriae in Capnodiaceae. Mycosphere 6, 814824.

Hughes SJ. 1976 - Sooty moulds. Mycologia 68, 693-820.

Hyde KD, Jones EBG, Liu JK, Ariyawansha H et al. 2013 - Families of Dothideomycetes. Fungal Diversity 63, 1-313.

Jamaluddin S, Goswami MG, Ojha BM. 2004 - Fungi of India (1989-2001). Scientific Publishers, Jodhpur, Rajasthan, India.

Khan I, Najeebullah S, Ali M, Shinwari ZK. 2016 - Phytopharmacological and ethnomedicinal uses of the Genus Berberis (Berberidaceae): A review. Tropical Journal of Pharmaceutical Research 15, 2047-2057. 
Laemmlen FF. 2011 - Sooty mold. Integrated pest management for home gardeners and landscape professionals. Pest notes, University of California. Agriculture and Natural Resources, USA. Retrieved November 12, 2012, from http://www.ipm.ucdavis.edu/PDF/ PESTNOTES/pnsootymold.pdf

Liu JK, Hyde KD, Jones EBG, Ariyawansa HA et al. 2015 - Fungal diversity notes 1-110: taxonomic and phylogenetic contributions to fungal species. Fungal Diversity 72, 1-197.

Montagne C. 1849 - De Capnodio. novum fungorum genus. Annales des sciences naturelles 3, 11:233-234.

Mukherji KG, Juneja RC. 1974 - Fungi of India: supplement to the list of Indian Fungi, 19621972. Emkay Publication, Delhi, India.

Rao VG. 1980 - Fungi on Citrus from India. Sydowia 23, 215-224.

Schoch CL, Crous PW, Groenewald JZ, Boehm EW et al. 2009 -A class-wide phylogenetic assessment of dothideomycetes. Studies in Mycology 64, 1-15.

Sharma JR, Mishra D. 2018 - Fungi of Karnataka- Check List. Botanical Survey of India (BSI) Northern Regional Canter, Dehradun, India.

Sood P, Modgil R, Sood M. 2012 - Berberis lycium a medicinal plant with immense value. Indian Journal of Pharmaceutical and Biological Research 1, 1-8.

Todawat NJ. 2017 - Sooty mould diseases of some trees from Aurangabad district, Maharashtra (India). Flora and Fauna 23, 351-353.

Wijayawardene NN, Crous PW, Kirk PM, Hawksworth DL et al. 2014 - Naming and outline of Dothideomycetes. Fungal Diversity 69, 1-55. 